\title{
A vetületválasztás hatása kis méretarányú térképek olvasására
}

\author{
Szigeti Csaba-Kerkovits Krisztián
}

DOI: https://doi.org/10.30921/GK.70.2018.2.3

\section{Bevezetés}

Az emberek a lakóhelyük környezetérôl elsősorban személyes tapasztalataik alapján alakítják ki kognitív térképüket. Távoli, vagy nagyobb területek esetében, ahol nincs lehetôség közvetlen ismeretszerzésre, a tudás bóvítése kis méretarányú térképek tanulmányozásával oldható meg.

A kis méretarányú térképeken található ismeretanyag valóságtartalma személyesen csak igen korlátozott mértékben ellenôrizhetô. A térkép olvasója tehát kénytelen valóságként elfogadni a látottakat. Ráadásul az ember nagyon fogékony a vizuális ingerekre, a grafikák, térképek képesek mélyen befolyásolni a világlátást. Ezt a közismert jelenséget számtalanszor használta már föl a politikai propaganda is (Jeney 2015).

Ezzel szemben a térképek valójában csak modellezik a földrajzi valóságot. A sík térképlapon például lehetetlen a görbült földfelszínt torzulásmentesen ábrázolni. A leképezésbôl adódó alak- és méretváltozásokat összefoglaló néven vetületi torzulásoknak vagy egyszerúen torzulásoknak (Hazay 1954) nevezzük. Ezek a torzulások különösen kis méretarányú térképeken okoznak szabad szemmel észlelhetô eltéréseket. A Föld síkban történô ábrázolása az olvasóban téves képzeteket alakíthat ki a földrajzi viszonyokról (BattersbyMontello 2009).

A létezô vetületek sokféleségének egyik oka, hogy mindegyikük más-más jellemzôket ad vissza a gömbi eredetinek megfelelôen, és másokat torzít. A leképezés során torzulhatnak a méretviszonyok, irányok, távolságok stb., mely torzulások mértékei különbözôek az egyes vetületekben. Alábbi kutatás arra keresi a választ, hogy mely torzulásokat kell különösen figyelembe venni a vetületválasztáskor, valamint az olvasó mennyire van tudatában a kis méretarányú térképek torzult voltának. Vizsgálatunkban ki kívántunk térni arra, hogy mely demográfiai változók (életkor, képzettség, térképhasználati gyakoriság) befolyásolják a vetületi torzulások helyes értelmezését.

Habár a térkép megfelelô vetületének megválasztása mindig is a térképszerkesztô feladata volt, korábban a hosszadalmas átszerkesztési feladat miatt korlátozott voltak a lehetôségek a térképek vetületeinek megváltoztatására. A digitális kartográfia megjelenésével azonban a térképszerkesztôk néhány kattintással megváltoztathatják a térképek vetületi beállításait. Ennek köszönhetôen mára megnyílt a lehetôség a hatékony és felhasználóbarát vetületválasztásra, amelyet tanulmányunkkal szeretnénk elôsegíteni.

Több kutatás is létezik, amely a térképolvasási képességet, valamint a térképolvasást befolyásoló tényezôket vizsgálja (pl. Gilhooly et al. 1988; Guzmán et al. 2008; Ito-Szano 2011, Ooms et al. 2012, Albert et al. 2016). Ezek a kutatások azonban kizárólag nagy méretarányú térképeket vizsgálnak. Vakabajasi (2013) bemutatta, hogy eltérô készségekre van szükség a kis és a nagy méretarányú térképeknél: míg az utóbbi esetben a kognitív tájékozódási és térképolvasási képesség befolyásolja a térkép értelmezését, addig az elôbbinél a földrajzi ismeretek dominálnak.

A vetületek és a térkép felhasználója közötti kapcsolattal ugyanakkor kevés irodalom foglalkozik. Vizsgálatunk motivációját egy úttörố kutatás (Šavrič et al. 2015) adta, melyben elsóként jártak utána, hogy a térképolvasók véleménye szerint milyen vetületben érdemes világtérképet készíteni. A kérdôívben nem szerepelt térképolvasási feladat, így az eredmények inkább a felhasználók esztétikai igényét mérték föl. A kitöltôk többsége amerikai és indiai származású; lehet, hogy ezért ért el az angolszász gyakorlatban sûrûn használt Robinson-vetület jobb eredményt, mint a kedvezőbb torzulású, inkább Európában kedvelt Winkel III. vetület. Ezt a feltevést alapozza meg a Kísérleti Térképészeti Kutatócsoport egyik eredménye, amely szerint a térképolvasást a kulturális háttér is befolyásolja (Albert et al. 2016). Mivel a mi kitöltôiink is adott kultúrkörhöz kötôdnek (kutatásunk magyar nyelven folyt), fontos hangsúlyozni, hogy a mi eredményeinket is befolyásolhatta a hazai kartográfiai gyakorlat.

Šavričék kutatása nem tért ki arra a kérdésre, hogy ha egy térkép egy, a felhasználók körében népszerú vetületben van, akkor azt valóban jobban lehet-e használni. Meg kell tehát vizsgálni, hogy a vetület mely torzulási tulajdonságai zavarják meg jobban a felhasználót a helyes információ leolvasásában.

Néhány konkrét torzító hatás vizsgálatáról születtek ugyan tanulmányok (Anderson-Leinhardt 2002, Battersby-Montello 2009, Hruby et al. 2016), de ezek közös jellemzóje, hogy kevés kitöltôvel és kizárólag földrajzszakosok körében dolgoztak. Egy kivétellel mindegyik kérdőívet csak egyetemi hallgatókkal töltették ki. A pontosabb eredmények érdekében szükséges az eredmények ellenôrzése szélesebb közönség bevonásával. Emellett további torzulási jellemzôket is meg kívántunk vizsgálni.

\section{A kutatás menete}

\section{A kérdốiv}

A vetületek értelmezhetôségét kérdőíves formában mértük fel, melyet magyar nyelvú internetes felületen tettünk elérhetôvé. Az első kérdések a demográfiai adatfelvételt (nem, életkor, végzettség, szakterület, térképhasználati gyakoriság) szolgálták. A teszt külön kitért arra, hogy a kitöltố a tanulmányait már befejezte, vagy még folytatja. Megkérdeztük emellett különbözô térképtípusok (világatlasz, földgömb, tematikus atlaszok, digitális földgömbök, online térképszolgálatatások) használatának gyakoriságát is (hetente 
többször, hetente, havonta, néhány havonta, ritkábban). A kitöltőket kétfelé, kísérleti és kontrollcsoportba osztottuk. A kísérleti csoport olyan vetületekkel dolgozott, amelyeken a vizsgált torzulás figyelmen kívül hagyása és a közvetlen leolvasás téves válaszadáshoz vezet. Ezzel szemben a kontrollcsoport térképei az adott szempontból torzulásmentesek, vagy elônyös torzulásúak voltak, valamint igyekeztünk számukra olyan vetületet választani, ahol a vetület elốnytelenebb tulajdonságai sem ébresztenek bizalmatlanságot. A teszt algoritmusa törekedett a kitöltôiinket a kísérleti és kontrollcsoport között úgy szétosztani, hogy mindkét csoportban lehetôleg azonos arányban szerepeljenek a különbözô demográfiai csoportok.

Hét térképolvasással kapcsolatos kérdést tettünk fel. Minden kérdésre egy helyes válasz volt, melyet hat lehetôség közül kellett kiválasztani. A kérdéseket „Nem tudom” válasszal át lehetett ugorni. A kérdések sorrendjét törekedtünk úgy megválasztani, hogy a korábban látott térképek lehetôleg ne befolyásolják a válaszadást. Például a megszokottabb vetületi szakadások helyes értelmezését előbb vizsgáltuk, mint a térkép közepén feltűnőbben jelentkezôkét. A kérdések szövege a két csoport részére azonos volt, de különbözố térképek alapján kellett válaszolniuk. A kitöltôket megkértük, hogy a kitöltés során kizárólag az általunk kiválasztott térképeket használják, segédeszközt ne vegyenek igénybe.

Kísérletünk célja az volt, hogy megvizsgáljuk, mely torzulások esetében mutatható ki döntô különbség a két csoport eredményei között, mert ebben az esetben biztosan kijelenthetjük: a rossz vetületválasztás miatt az olvasó várhatóan helytelen következtetéseket von le a térképrôl.

\section{Adatgyújtés}

Az adatok gyújtését 2017. január 23. és április 13. között végeztük. Ez idô alatt az online tesztünkre összesen 322 kitöltés érkezett. Ezek közül 247 et dolgoztunk fel, mert a kitöltések közül kiszúrtük a befejezetlen teszteket. Átlagosan 5,5 perc volt a tesztek kitöltése. Az elfogadható kitöltési határ minimumát 2 perc 21 másodpercnél, maximumát 14 perc 29 másodpercnél jelöltük ki. Az ezeket alul- vagy túllépô tesztkitöltéseket szintén nem vettük be a kiértékelésbe. Ennek oka, hogy a túl rövid kitöltési idô tippelésre engedett következtetni, míg a túl hosszú kitöltés a kérdôív idôközbeni megszakítását jelezte. Az idôkorlátokat az adatsorban látható természetes törések alapján határoztuk meg.

\section{A kitöltôk bemutatása}

A kitöltôk demográfiai jellemzóit az 1. ábra mutatja be. A résztvevôket különböző demográfiai csoportba lehetett beosztani. A főbb tényezók a következôk voltak: nem (férfiak, nôk), életkor (20 év alattiak, 21-25 év közöttiek, 26-30 év közöttiek, 30 év felettiek), iskolai végzettség (alapfokú, középfokú, felsôfokú), földrajz- és földtudományokban való képzettség, térképhasználat gyakorisága (ritka, közepesen gyakori, gyakori).

A nemek eloszlása a kitöltôk közt közel azonosnak mondható: 128 férfi és 119 nó vett részt a kutatásban. 136 kitöltô került a kísérleti

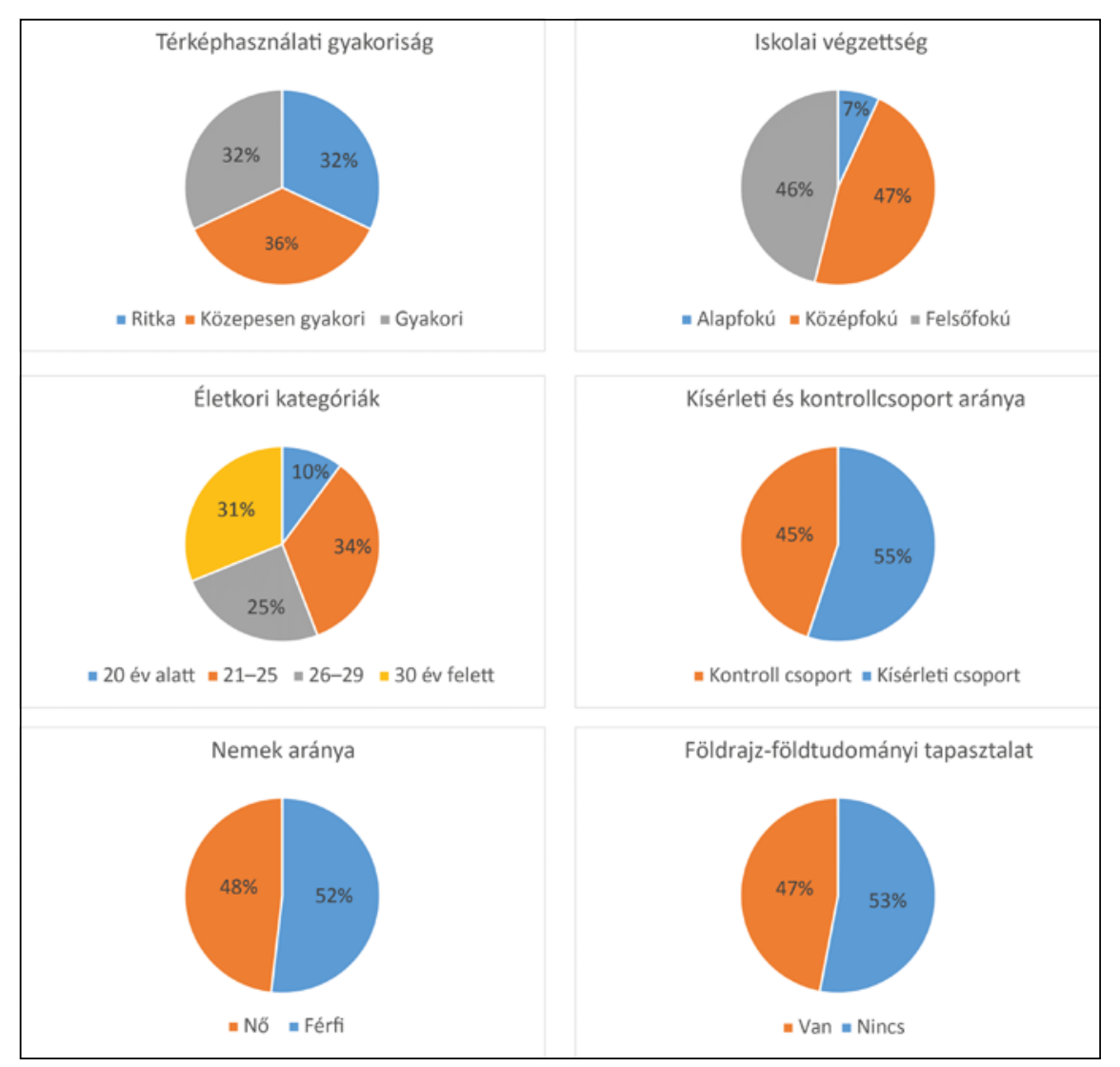

1. ábra. A kitöltôk demográfiai jellemzô

csoportba, míg 111 kitöltốt soroltunk a kontrollcsoportba.

Az iskolai végzettség szerint $114 \mathrm{fel}$ sôfokú, 116 középfokú, és 17 alapfokú végzettségú személy töltötte ki a tesztet. A földrajz- és földtudományi képzéseken tanultak aránya a férfiak esetében közel egyforma volt: 68 fố ezen a területen tanult, míg 60 fó egyéb területen. A nôk esetében 48 fó volt jártas ezen a területen, míg 71 fố egyéb területen.

A térképhasználati gyakoriságot figyelembe véve 79 fố ritkán, 89 fô közepesen gyakran és 79 fó gyakran olvas térképet a kitöltôk közül.

Fontos megjegyezni, hogy jelen kutatás feltáró jellegú, és nem volt célja reprezentatív eredmények létrehozása.

\section{Eredmények}

A kísérleti és a kontrollcsoport eredményeit összehasonlítva megvizsgálhatjuk, hogy mennyivel találták a kitöltôk könnyebbnek a feladathoz ideálisabb vetületet. A kísérleti csoport esetében a legtöbb kitöltô 4 helyes választ adott a 7-bôl (a kitöltốk 27,2\%-a), míg a kontrollcsoportban 5 helyes válasz fordult elô a leggyakrabban (27\%). A kísérleti 
és kontrollcsoport közti különbségeket tovább lehet árnyalni, ha az egyes demográfiai változók szerint is megvizsgáljuk az eredményeket.

A statisztika tudományágának alapvetô problémája, hogy nincs lehetôség a teljes populáció vizsgálatára, a mintavétel alapján számított empirikus értékek a mintavétel miatt torzított becslést szolgáltatnak. Ha szeretnénk megállapítani, hogy a kísérleti és kontrollcsoport eredményei között tapasztalt különbséget a mintavételből fakadó bizonytalanság, vagy tényleges eltérés okozza, ún. statisztikai próbát kell végrehajtani. Egy ilyen statisztikai próba sohasem tud biztos állításokat kimondani, következtetéseinket egy adott valószínúségi szint mellett hozzuk meg. Kutatásunkhoz az általánosan elterjedt t-teszt segítségével választottuk szét a mintavétel és a vetületválasztás okozta eredménykülönbségeket. Az érdeklődô a próba matematikai hátterérôl többek között Tóthné (2011) tankönyvében tájékozódhat.

A továbbiakban szignifikánsnak nevezzük a különbséget, ha a t-teszt szerint legalább 95\% valószínúséggel állíthatjuk, hogy a vetületválasztás befolyásolta a válaszadást (tehát az ún. $p$ szignifikanciaszint kisebb, mint 0,05). Természetesen attól még, hogy a t-teszt nem talál szignifikáns eltérést, a valóságban befolyásolhatta a vetületválasztás az eredményeket.

Az 1. táblázatban észrevehetô, hogy statisztikailag szignifikáns eltérés lép fel a két csoport eredménye közt több demográfiai változó esetében is. A két csoport közti különbséget megvizsgáltuk az egyes vetületi hatások esetében is.

\section{Feladatok szerinti bontás}

\section{Területtorzulás}

Battersby és Montello (2009) kutatása kimutatta, hogy a térképen található területtorzulásokkal a térképolvasók tisztában vannak, sôt az ô felmérésükben a tesztalanyok a torzulásokat túlkompenzálták. Mivel ebben a vizsgálatban kizárólag földrajz szakos hallgatók vettek részt, fontosnak tartottuk az eredmény ellenőrzését szélesebb közönség vizsgálatával.

A helyes válaszok eloszlása demográfiai változók szerint Megjegyzés: a kékkel kiemelt mezők szignifikánsan eltérnek kontroll/kísérleti csoport párjuktól kétoldalú t-teszt (p<0,05) alapján

\begin{tabular}{|c|c|c|c|c|c|c|c|c|c|c|c|c|}
\hline & \multicolumn{4}{|c|}{ Nemek } & \multicolumn{8}{|c|}{ Életkor szerinti kategóriák } \\
\hline & \multicolumn{2}{|c|}{ Férfi } & \multicolumn{2}{|c|}{ Nố } & \multicolumn{2}{|c|}{20 év alatt } & \multicolumn{2}{|c|}{$21-25$} & \multicolumn{2}{|c|}{$26-30$} & \multicolumn{2}{|c|}{30 év felett } \\
\hline & $\begin{array}{l}\text { Kísérleti } \\
\text { csoport }\end{array}$ & $\begin{array}{l}\text { Kontroll } \\
\text { csoport }\end{array}$ & $\begin{array}{l}\text { Kísérleti } \\
\text { csoport }\end{array}$ & $\begin{array}{l}\text { Kontroll } \\
\text { csoport }\end{array}$ & $\begin{array}{l}\text { Kísérleti } \\
\text { csoport }\end{array}$ & $\begin{array}{l}\text { Kontroll } \\
\text { csoport }\end{array}$ & $\begin{array}{l}\text { Kísérleti } \\
\text { csoport }\end{array}$ & $\begin{array}{l}\text { Kontroll } \\
\text { csoport }\end{array}$ & $\begin{array}{l}\text { Kísérleti } \\
\text { csoport }\end{array}$ & $\begin{array}{l}\text { Kontroll } \\
\text { csoport }\end{array}$ & $\begin{array}{l}\text { Kísérleti } \\
\text { csoport }\end{array}$ & $\begin{array}{l}\text { Kontroll } \\
\text { csoport }\end{array}$ \\
\hline Területtorzulás & $30,6 \%$ & $32,1 \%$ & $26,6 \%$ & $30,9 \%$ & $15,4 \%$ & $16,7 \%$ & $20,0 \%$ & $25,6 \%$ & $27,3 \%$ & $39,3 \%$ & $42,2 \%$ & $37,5 \%$ \\
\hline Meridiánkonvergencia & $83,3 \%$ & $67,9 \%$ & $82,8 \%$ & $72,7 \%$ & $84,6 \%$ & $83,3 \%$ & $82,2 \%$ & $64,1 \%$ & $78,8 \%$ & $64,3 \%$ & $86,7 \%$ & $78,1 \%$ \\
\hline Ellenmeridián & $56,9 \%$ & $66,1 \%$ & $50,0 \%$ & $56,4 \%$ & $61,4 \%$ & $58,3 \%$ & $64,4 \%$ & $59,0 \%$ & $45,5 \%$ & $64,3 \%$ & $46,7 \%$ & $62,5 \%$ \\
\hline Szakadások & $34,7 \%$ & $51,8 \%$ & $43,8 \%$ & $52,7 \%$ & $38,5 \%$ & $50,0 \%$ & $44,4 \%$ & $56,4 \%$ & $39,4 \%$ & $57,1 \%$ & $33,3 \%$ & $43,8 \%$ \\
\hline Fokhálózat értelmezése & $95,8 \%$ & $91,1 \%$ & $95,3 \%$ & $94,5 \%$ & $84,6 \%$ & $91,7 \%$ & $95,6 \%$ & $89,7 \%$ & $100,0 \%$ & $92,9 \%$ & $95,6 \%$ & $96,9 \%$ \\
\hline Pólusvonalak értelmezése & $43,1 \%$ & $76,8 \%$ & $20,3 \%$ & $76,4 \%$ & $15,4 \%$ & $83,3 \%$ & $33,3 \%$ & $71,8 \%$ & $36,4 \%$ & $71,4 \%$ & $33,3 \%$ & $84,4 \%$ \\
\hline Második irányredukció & $47,2 \%$ & $37,5 \%$ & $37,5 \%$ & $41,8 \%$ & $15,4 \%$ & $41,7 \%$ & $37,8 \%$ & $33,3 \%$ & $36,3 \%$ & $32,1 \%$ & $60,0 \%$ & $53,1 \%$ \\
\hline
\end{tabular}

\begin{tabular}{|c|c|c|c|c|c|c|c|c|c|c|}
\hline & \multicolumn{6}{|c|}{ Végzettség szerinti kategóriák } & \multicolumn{4}{|c|}{ Földrajz-földtudományi tapasztalat } \\
\hline & \multicolumn{2}{|c|}{ Alapfokú } & \multicolumn{2}{|c|}{ Középfokú } & \multicolumn{2}{|c|}{ Felsôfokú } & \multicolumn{2}{|c|}{ Nincs } & \multicolumn{2}{|c|}{ Van } \\
\hline & $\begin{array}{l}\text { Kísérleti } \\
\text { csoport }\end{array}$ & $\begin{array}{l}\text { Kontroll } \\
\text { csoport }\end{array}$ & $\begin{array}{l}\text { Kísérleti } \\
\text { csoport }\end{array}$ & $\begin{array}{l}\text { Kontroll } \\
\text { csoport }\end{array}$ & $\begin{array}{l}\text { Kísérleti } \\
\text { csoport }\end{array}$ & $\begin{array}{l}\text { Kontroll } \\
\text { csoport }\end{array}$ & $\begin{array}{l}\text { Kísérleti } \\
\text { csoport }\end{array}$ & $\begin{array}{l}\text { Kontroll } \\
\text { csoport }\end{array}$ & $\begin{array}{l}\text { Kísérleti } \\
\text { csoport }\end{array}$ & $\begin{array}{l}\text { Kontroll } \\
\text { csoport }\end{array}$ \\
\hline Területtorzulás & $10,0 \%$ & $28,6 \%$ & $25,8 \%$ & $24,1 \%$ & $34,4 \%$ & $40,0 \%$ & $22,5 \%$ & $30,0 \%$ & $35,4 \%$ & $33,3 \%$ \\
\hline Meridiánkonvergencia & $70,0 \%$ & $71,4 \%$ & $79,0 \%$ & $68,5 \%$ & $89,1 \%$ & $72,0 \%$ & $81,7 \%$ & $66,7 \%$ & $84,6 \%$ & $74,5 \%$ \\
\hline Elleneridián & $50,0 \%$ & $57,1 \%$ & $56,5 \%$ & $59,3 \%$ & $51,6 \%$ & $64,0 \%$ & $53,5 \%$ & $63,3 \%$ & $53,3 \%$ & $58,5 \%$ \\
\hline Szakadások & $50,0 \%$ & $57,1 \%$ & $38,7 \%$ & $57,4 \%$ & $37,5 \%$ & $46,0 \%$ & $40,8 \%$ & $53,3 \%$ & $36,9 \%$ & $51,0 \%$ \\
\hline Fokhálózat értelmezése & $80,0 \%$ & $100,0 \%$ & $95,2 \%$ & $92,6 \%$ & $98,4 \%$ & $92,0 \%$ & $94,4 \%$ & $91,7 \%$ & $96,9 \%$ & $94,1 \%$ \\
\hline Pólusvonalak értelmezése & $10,0 \%$ & $100,0 \%$ & $29,0 \%$ & $74,1 \%$ & $39,1 \%$ & $76,0 \%$ & $28,2 \%$ & $80,0 \%$ & $36,9 \%$ & $72,5 \%$ \\
\hline Második irányredukció & $10,0 \%$ & $42,8 \%$ & $38,7 \%$ & $37,0 \%$ & $51,6 \%$ & $42,0 \%$ & $35,2 \%$ & $40,0 \%$ & $50,7 \%$ & $39,2 \%$ \\
\hline
\end{tabular}

\begin{tabular}{|c|c|c|c|c|c|c|}
\hline & \multicolumn{6}{|c|}{ Térképolvasási gyakoriság } \\
\hline & \multicolumn{2}{|c|}{ ritka } & \multicolumn{2}{|c|}{ közepes } & \multicolumn{2}{|c|}{ gyakori } \\
\hline & Kísérleti csoport & Kontroll csoport & Kísérleti csoport & Kontroll csoport & Kísérleti csoport & Kontroll csoport \\
\hline Területtorzulás & $11,9 \%$ & $27,0 \%$ & $38,0 \%$ & $28,2 \%$ & $34,1 \%$ & $40,0 \%$ \\
\hline Meridiánkonvergencia & $83,3 \%$ & $73,0 \%$ & $80,0 \%$ & $66,7 \%$ & $86,4 \%$ & $71,4 \%$ \\
\hline Elleneridián & $52,4 \%$ & $59,5 \%$ & $52,0 \%$ & $64,1 \%$ & $56,8 \%$ & $60,0 \%$ \\
\hline Szakadások & $31,0 \%$ & $51,4 \%$ & $44,0 \%$ & $48,7 \%$ & $40,9 \%$ & $57,1 \%$ \\
\hline Fokhálózat értelmezése & $95,2 \%$ & $89,2 \%$ & $96,0 \%$ & $92,3 \%$ & $95,5 \%$ & $97,1 \%$ \\
\hline Pólusvonalak értelmezése & $31,0 \%$ & $86,5 \%$ & $38,0 \%$ & $66,7 \%$ & $27,3 \%$ & $77,1 \%$ \\
\hline Második irányredukció & $33,3 \%$ & $37,8 \%$ & $52,0 \%$ & $43,6 \%$ & $40,9 \%$ & $37,4 \%$ \\
\hline
\end{tabular}


A fent idézett kutatáshoz hasonlóan a térképi terület leolvasását nem négyzetkilométerben végeztük el, hanem egy referenciafelületet (Grönland) véve egységnek. A kitöltőknek azt kellett megválaszolniuk, hogy Afrika területe hányszorosa Grönlandénak. A két terület különbözô földrajzi szélességen helyezkedik el, ezért a gyakorlatban használt vetületekben jelentős különbségek léphetnek fel a méretviszonyokban.

A kísérleti csoport számára Battersbyék a Mercator-vetületet választották, mert az igen népszerú az amerikai kartográfiai gyakorlatban. Ezt a vetületet a magyar térképészek világtérképekre nem szokták alkalmazni, ezért mi a magyar nyelvú világatlaszokban elterjedtebb, hasonlóan kedvezôtlen Van der Grinten I. vetületet választottuk (2. ábra).

A kontrollcsoport a feladatát területtartó térképen végezte. Nem akartuk, hogy a vetület túlzott szögtorzulásai bizalmatlanságot ébresszenek, ezért a világtérképek számára kedvezőbb Wagner-transzformált Hammervetületú térképen dolgozhattak (2. ábra). A teljesen torzulásmentes földgömb alkalmazására az internetes felület sajátosságai miatt nem volt lehetôség, hiszen a virtuális glóbuszok is csak valamilyen perspektív vetületben jelennek meg a sík képernyőn, melynek torzulásai befolyásolhatták volna a vizsgálatot.

A kísérleti csoport $28,7 \%$-a válaszolt helyesen, miszerint tizenötször nagyobb Afrika Grönlandnál. A leggyakrabban jelölt helytelen válasz, 26,5\%-kal az ötszörös méretkülönbség volt. Ezzel szemben a kontrollcsoport 31,5\%-a jelölte meg a helyes választ, de 33,3\%-uk a helytelen, ötszörös méretkülönbséget jelölte meg.

Nem jelentkezett szignifikáns különbség egyik demográfiai csoport eredményében sem. Ennek ellenére észrevehetô, hogy a 26-30 év közöttieket a többi korcsoporthoz képest jelentôsebben befolyásolta az alkalmazott vetület. Hasonló jelenség figyelhetố meg a földrajzban nem járatos kitöltôk, valamint a térképet ritkán használók esetében is.

A kitöltők jelentôs része tehát alábecsülte Afrika területét, kisebbnek gondolták a két terület közti különbséget. A jól megválasztott vetület a térképet ritkán olvasóknak, az alapfokú végzettségúeknek és a földrajz-földtudományokban kevésbé jártas kitöltôknek segített, mivel ezek a csoportok térképolvasás közben kisebb mértékben számoltak a vetületi torzulásokkal.

\section{Meridiánkonvergencia}

A térképen az irányok elméletileg úgy olvashatóak le, hogy a térkép teteje megegyezés szerint észak felé néz, és a térképolvasó a térkép függőleges tengelyével bezárt szög alapján bármely szakasz azimutját meg tudja becsülni. A gyakorlatban ezt a vetület három tulajdonsága befolyásolja (Hazay 1954): A vetületi meridiánkonvergencia (a sík térkép bizonyos pontjain észak nem pontosan fölfelé van), az elsố irányredukció (a térképi szögek általában nem egyeznek meg a földi megfelelőjükkel) és a második irányredukció (a geodéziai vonalak - két pont közti legrövidebb útvonalak - rendszerint görbe vonalakként jelentkeznek a térképen).

Az irányok helyes leolvasását külön vizsgáltuk a kis és a nagy távolságoknál, utóbbit az utolsó kérdésben részletezzük. Kis távolságok esetén az elsố irányredukció elhanyagolható, mert rövid szakaszok irányát regionális térképekrôl olvashatjuk le, melynek szögtorzulása értelmes vetületválasztás esetén a $10^{\circ}$-ot jellemzốen nem haladja meg. A második irányredukció figyelmen kívül hagyása szintén csak néhány fok hibát okoz. Ezzel szemben feladatunkban a meridiánkonvergencia figyelmen kívül hagyása már $60^{\circ}$ hibát okoz, mely már kis méretarányú térképek olvasásakor is számottevô.

A nagyjából szélességi kör mentén húzódó Oroszországot kúpvetületben

\section{Kísérleti térkép}

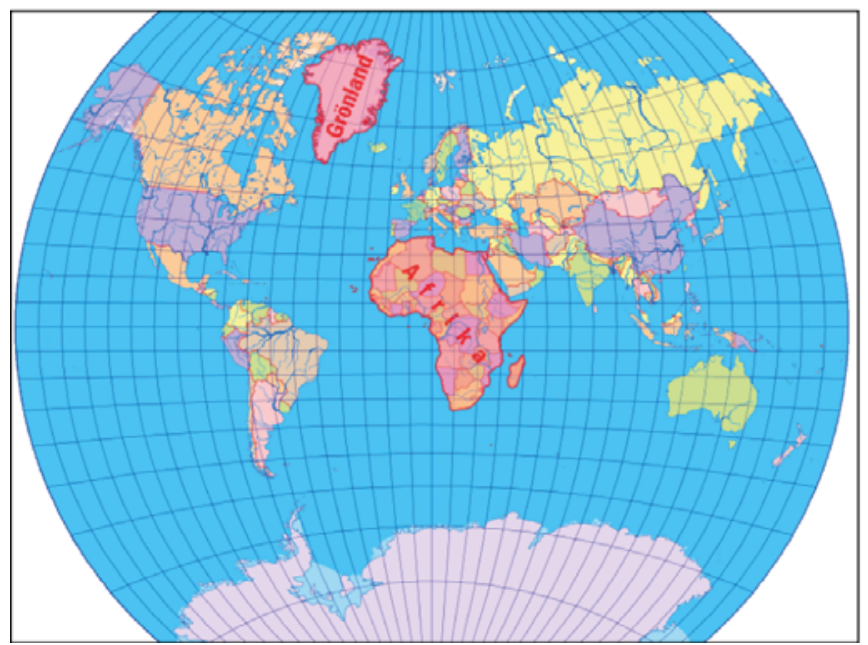

Kontrolltérkép

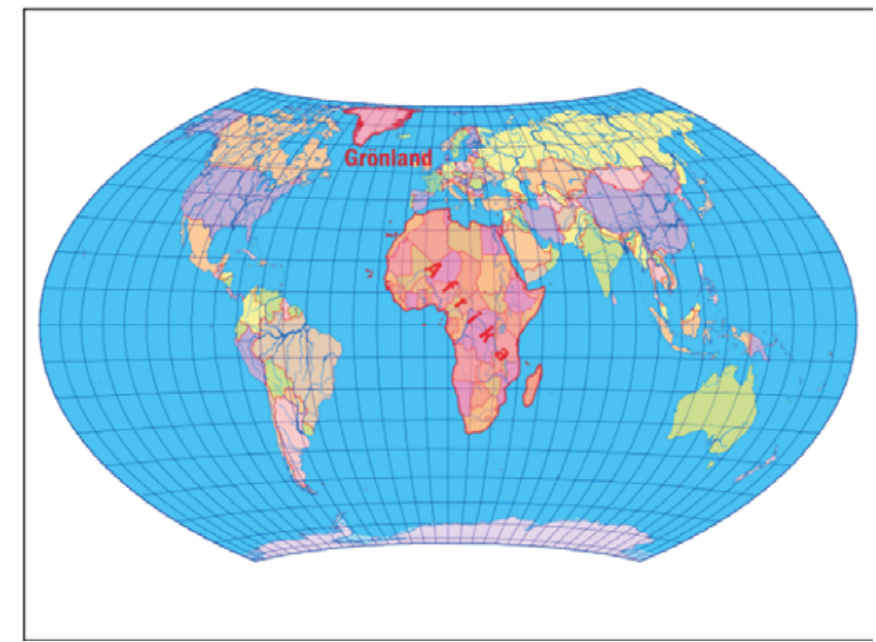

Hányszor nagyobb Afrika területe a valóságban, mint Grönlandé?

\begin{tabular}{|l|l|l|}
\hline A) egyforma & B) másfélszer & C) háromszor \\
\hline D) ötször & E) tizenötször & F) huszonötször \\
\hline
\end{tabular}

2. ábra. A területtorzulást vizsgáló feladat térképei (a helyes válasz félkövérrel kiemelve) 
szokás ábrázolni, melynek torzulásai kedvezôknek mondhatók. A magas szélesség- és a nagy hosszúságkülönbségek miatt azonban a meridiánok képei erôsen összetartanak, a Csukcs-félsziget a térkép szélén „fölkanyarodik". Az ilyen vetületekben a Csukcsföldön fölfelé mutató nyíl már nem északi, hanem kelet-északkeleti irányba mutat. A kísérleti alanyoknak több lehetôség közül ezt az égtájat kellett megjelölniük. Kísérleti csoportunk ennek megfelelően egy De l'Isle-kúpvetületen dolgozott, az I. irányredukciót $\left(3^{\circ}\right)$ elhanyagoltuk (3. ábra).

A normális elhelyezésú valódi hengervetületeken a meridiánok nem konvergálnak. Ha emellett a szögtartást is kikötnénk, Mercator vetületét kapnánk, mely ilyen magas szélességeken alkalmazhatatlan. Így a kontrollcsoportnak Gall kváziperspektív hengervetületét választottuk, melynek torzulásai kevésbé zavaróak, és az I. irányredukció $\left(7^{\circ}\right)$ ismételten elhanyagolható (3. ábra). A nyíl ebben az esetben értelemszerúen már nem fölfelé mutatott.

A kísérleti csoport 83\%-a jelölte meg helyesen, hogy a nyíl kelet-északkelet felé mutat. A többi lehetôséget közel azonos arányban jelölték a kitöltôk. Ezzel szemben, a kontrollcsoport 70,3\%-a jelölte meg a helyes választ, és a csoport tagjainak $13,5 \%$-a helytelenül az északot jelölte meg.

Statisztikailag szignifikánsan jobb eredményt értek el a megszokott vetületben lévố kísérleti térképeket használó férfiak, mint a szokatlanabb megjelenésû kontrolltérképeket használók. A nốk esetében szintén jobban teljesítettek a kísérleti térképeket használók, bár nem jelentkezett számszakilag kimutatható eltérés. Az összes korcsoport esetében jobb eredményt ért el a kúpvetületet használó kísérleti csoport, a legjelentôsebb különbség a 21-25 év közöttiek esetében vehetô észre. Az iskolai végzettség tekintetében a felsőfokú végzettséggel rendelkezô kitöltôk a felmérés alapján határozottan jobb eredményt értek el a kísérleti térképpel. Ugyanez a jelenség észrevehetô a földrajzban nem jártas tesztalanyok esetében is. Az egyik térképhasználói csoport esetében sem vehetố észre jelentős különbség a kísérleti és kontrolltérkép használata közt.

A kedvezó vetület inkább hátráltatta mintsem segítette a térkép értelmezését. Az eredmények azt mutatják, hogy a meridiánkonvergencia nem zavarja az iránymeghatározást, mivel a térképolvasók a fokhálózatot használják segítségként. Ugyanakkor a kontrolltérkép vetületének szokatlan ábrázolásmódja megzavarhatta a térképolvasást.

\section{Szakadások az ellenmeridiánon}

Egy normális elhelyezésú vetület ellenmeridiánjának nevezzük azt a hosszúsági kört, amely a vetület függóleges szimmetriatengelyén futó középmeridiántól $180^{\circ}$-ra helyezkedik el. A legtöbb vetület ezt a vonalat kétszeresen képezi le a síkra úgy, hogy az ellenmeridián képei adják a térkép keleti és nyugati kontúrvonalát. E miatt az ellenmeridián közelében, a valóságban kis távolságokra elhelyezkedô pontpárok a térkép átellenes pontjaira képzôdnek le, rontva a globális kapcsolatok szemléletes megjelenítését.

Egy közelmúltban megjelent dolgozatban (Gott et al. 2007) kiszámolták azt a vetületet, amely globális távolságokat a lehetô legkisebb hibával képzi le. A kutatók (bár ezt maguk nem vették észre) a Ginzburg-sor egyik vetületét kapták eredményül, melyrôl már régóta ismert, hogy optimális torzulású (Tolsztova 1969). Gotték a számítás során az ellenmeridián közelében lévô pontokat is egyenes vonallal, a teljes térképen keresztül kötötték össze, ezzel implicite feltételezve, hogy a térképolvasó sem helyesen, a térkép szélén keresztül, két szakaszban becsli a távolságot. Hiányzott azonban ezen feltételezés megalapozása.

Az ellenmeridián hatását tényleges kísérletekkel csak késôbb vizsgálták

\section{Kísérleti térkép}
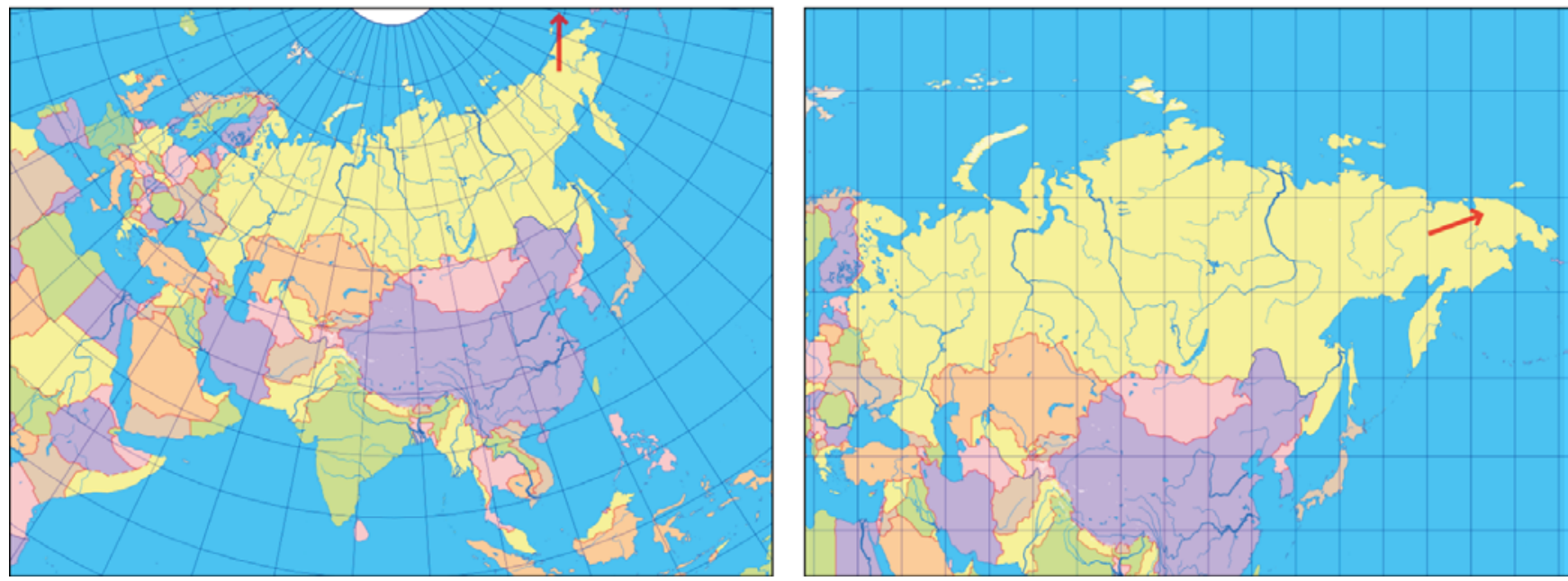

\begin{tabular}{|l|l|l|}
\hline \multicolumn{4}{|c|}{ Milyen égtáj felé mutat a piros nyíl Csukcsföldön? } \\
\hline A) észak & B) dél-délnyugat & C) kelet \\
\hline D) északnyugat & E) dél & F) kelet-északkelet \\
\hline \multicolumn{3}{|c|}{ 3. ábra. A meridiánkonvergenciát vizsgáló feladat térképei }
\end{tabular}

\section{Kontrolltérkép}


(Hruby et al. 2016). A kutatást ebben az esetben is kizárólag földrajz szakos hallgatók bevonásával végezték, így indokolt annak kiterjesztése szélesebb közönségre. A kísérleti alanyok - Gotték feltevésével ellentétben helyes irányba kötötték össze a pontpárokat, az átlagos távolságbecslési hiba nem haladta meg a $2 \%$-ot, melybe az erôsen torzító négyzetes hengervetület hatása is beleszólhatott. Ezzel együtt Hruby kutatócsoportja bizonyította az ellenmeridián zavaró hatását, mert kísérletükben az adatok alapján nyilvánvalóan jobban teljesítettek azok a hallgatók, akiknek a távolságokat nem a vetület ellenmeridiánján keresztül kellett mérni.

Mivel mi nem akartuk, hogy a vetület más torzító hatásai befolyásolják az eredményt, kísérletünket Baranyi IV. vetületén végeztük, mely az egész bolygóra nézve kedvezőnek mondható, és elterjedt a magyar gyakorlatban (4. ábra). A résztvevôknek három pontpárt kellett sorba rendezniük azok valós földi távolsága szerint. A három pontpárból kettôt az ellenmeridiánon kellett összekötni, de csak egy pontpárt helyeztünk annyira közel az ellenmeridiánhoz, hogy azok ilyen módon történô helyes összekötése magától értetôdô legyen.

A kontrollcsoport a szakadást csak egyetlen pontban tartalmazó, a földi távolságokat optimálisan ábrázoló Ginzburg-féle síkvetületet (Gott et al. 2007) kapta. A vetületet ferde tengelyú elhelyezésben alkalmaztuk, hogy a vizsgált pontokon ne lépjen föl bizalmatlanságot ébresztô torzulás (4. ábra).

A kísérleti csoport 53,7\%-a adott helyes választ. A kontrollcsoport esetében a résztvevôk 61,3\%-a jelölte meg a helyes választ. A leggyakoribb hiba az Auckland-Lima távolság helytelen értelmezésébôl fakadt (1. 4. ábra): A kísérleti csoport 25,0\%-a az ellenmeridiántól távol esô pontokat már nem a térkép szélén keresztül, hanem a belsô területén keresztül kötötte össze, és az így messzebbinek tûnt, mint a közel ellenlábas Dakka és Manaus távolsága. A kontrollcsoport esetén ez a hiba kevésbé jellemző, csak $12,6 \%$ volt

Egyik csoportnál sem vehetô észre szignifikáns különbség a kísérleti és kontrollcsoportok közt. Észrevehetô, hogy a többi korcsoporttal ellentétben a 25 év alattiaknál a kísérleti csoport teljesített jobban.
Az ellenmeridiánon fellépó szakadást Hruby et. al. (2016) egy pszichológiai határnak tartja. Ezzel szemben az eredményeink ennek ellenkezőjét mutatják: egyik csoportnál sem lépett fel statisztikailag egyértelmú különbség a kísérleti és kontrollcsoport eredménye között. Bár néhány kitöltôt nagy távolságok esetén valóban megzavart az ellenmeridián kétszeri megjelenítése, de a vártnál jelentôsen kisebb eltérés volt a két vetület esetében.

\section{Szakadások a térkép belsejében}

Bár a térképi ábrázolás folytonossága a legtöbb vetületben csak az ellenmeridián mentén szakad meg, a torzulások csökkentése céljából előfordulhatnak még további helyeken is szakadások. Származtatásuktól függően osztott vagy poliéder vetületeknek hívjuk az ilyen leképezéseket. Jó marketingképességekkel rendelkező nem szakmabeliek idôrốl-idôre „fölfedezik” a poliédervetületek kedvezóbb torzulásaiban rejlố lehetôségeket, melyet a bulvármédia szívesen fölkap. Ezt követôen a térképész szakma részérôl rendszerint negatív válasz érkezik, melyben jelzik, hogy a poliédervetületek kisebb

\section{Kísérleti térkép}

\section{Kontrolltérkép}
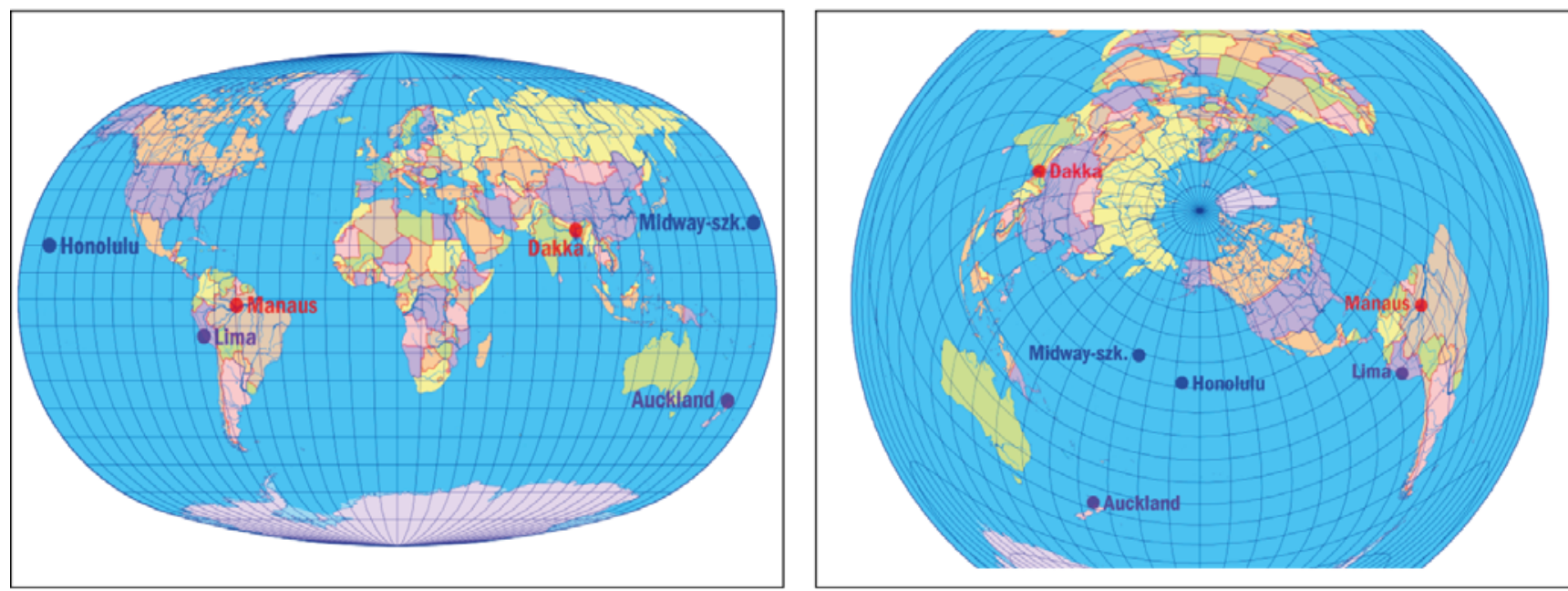

Rendezze a valós földi távolság szerint növekvô sorrendbe a pontpárokat (a legközelebbitôl a legtávolabbiig)

\begin{tabular}{|l|l|l|}
\hline A) Auckland-Lima; & B) Dakka-Manaus; & C) Auckland-Lima; \\
Dakka-Manaus; & Auckland-Lima; & Midway-szk.-Honolulu; \\
Midway-szk.-Honolulu & Midway-szk.-Honolulu & Dakka-Manaus \\
\hline $\begin{array}{l}\text { D) Midway-szk.-Honolulu; } \\
\text { Auckland-Lima; }\end{array}$ & E) Dakka-Manaus; & Midway-szk.-Honolulu; \\
Dakka-Manaus & Auckland-Lima & $\begin{array}{l}\text { F) Midway-szk.-Honolulu; } \\
\text { Dakka-Manaus; } \\
\text { Auckland-Lima }\end{array}$ \\
\hline
\end{tabular}

4. ábra. Az ellenmeridián hatását vizsgáló feladat térképei 
torzultságáért cserébe a térkép szerkezete szétesik, egymáshoz a valóságban közel esố objektumok a térképen egymástól messze kerülnek. A tudományos vita jelenleg is zajlik (Böhm et al. 2017).

Ugyan Hrubyék korábban említett dolgozatából kiderül, hogy a szakadások a távolságbecslésben kis mértékben megzavarják a térképolvasót, meg kívántuk határozni, hogy poliéder vetületek szakadásai a szokványos szakadásoktól eltérően befolyásolják-e a térképolvasást.

A kísérleti csoport térképvetületének Waterman pillangóvetületét választottuk, melynek alkotója szintén nem térképész, ugyanakkor a vetület megfelel a vetülettan hagyományos elôírásainak (szimmetrikus fokhálózat, explicit képletekkel felírható szerkesztési utasítás), torzulásai kedvezóek (5. ábra). A kitöltôknek egy szakadást nem keresztező szakaszt (New York-Birmingham) egységnek véve kellett egy szakadást keresztezô szakasz (Pretoria-Túzföld) hosszát meghatározniuk. A kontrollcsoport tagjai ugyanezt a feladatot az alig kedvezótlenebb, de szakadást nem tartalmazó Winkel III. vetületben oldották meg (5. ábra).
A kísérleti csoport 39\%-a jelölte meg helyesen, hogy másfélszeres a különbség a két távolság közt. A leggyakoribb helytelen választ, miszerint a távolság közel egyforma, a csoport 31,6\%-a jelölte meg. Ezzel szemben a kontrollcsoport 52,3\%-a becsülte meg helyesen a távolságot, és 27\%-uk gondolta azonosnak a két távot.

A demográfiai változókat figyelembe véve is minden esetben jobban teljesített a kontrollcsoport. A középfokú végzettségúek esetében ez a különbség szignifikáns eltérést mutat.

Gott et. al. (2007) véleménye szerint ugyanannyira nemkívánatos, ha két pont egy szakadás miatt kerül messze egymástól, mint ha a vetületi hossztorzulások okoznának ugyanekkora távolságnövekedést. Más szerzôk ezzel egybehangzóan az állítják, a térképkereten keresztül mért távolságokat a térképolvasók jellemzóen felülbecsülik (Hirtle-Jonides 1985, Hruby et. al. 2016). Ennek az eredményeink ellentmondanak, ugyanis leginkább az alábecslés volt a jellemzô hiba a kísérleti térképen. Emellett, egyedül a középfokú végzettségúek esetében lehetett megfigyelni számszerûen kimutatható különbséget a kontrolltérkép javára, amiból arra lehet következtetni, hogy a szakadások jelentéktelen mértékben rontják a távolságbecslést.

\section{Földrajzi övezetesség}

A térképolvasói preferenciák tekintetében kimutatható, hogy az egyenes szélességi körök kedveltebbek a görbéknél (Šavrič et al. 2015), bár a felmérés csak világtérképekre terjedt ki. Az egyenesre képződô szélességi körök vitathatatlan elônye, hogy szemléletesen mutatatják be a földrajzi övezetességet.

Feladatunkban északról dél felé haladva kellett négy pontot sorba rendezni. A kísérleti csoport ferde tengelyú Lambert-síkvetületet kapott (6. ábra). A vetület fontos tulajdonsága, hogy lehetőség van a pontként megjelenố póluson túli terület ábrázolására. A térképen elhelyeztünk pontot az Északi-sark képénél „északabbra” is. A kontrollcsoport ugyanezen pontokat a földrajzi övezetességet megôrzô Kavrajszkij VII. vetületében rendezte sorba (6. ábra). A vetület a gyakorlatban használt képzetes hengervetületek közül a legelônyösebbek közé sorolható.

\section{Kísérleti térkép}

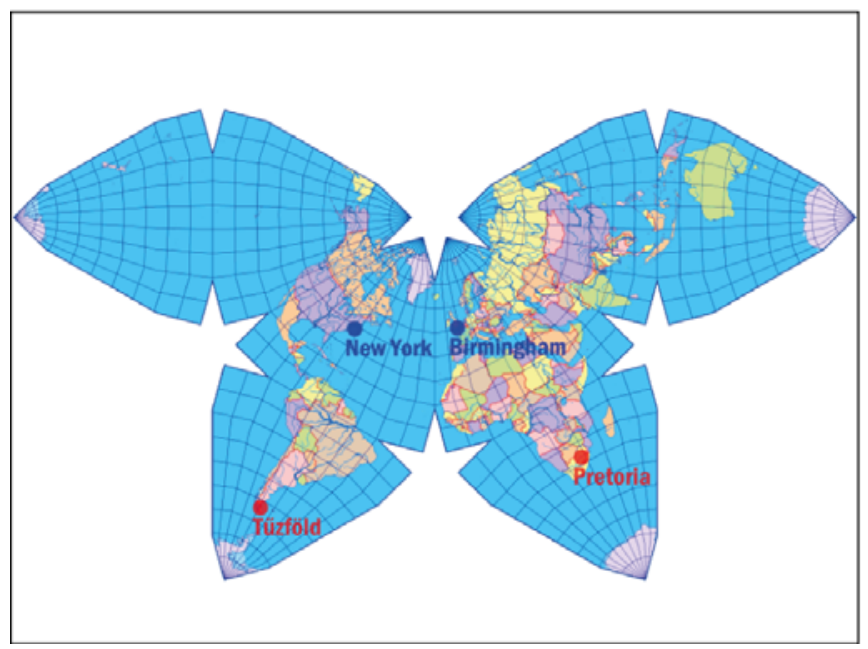

Kontrolltérkép

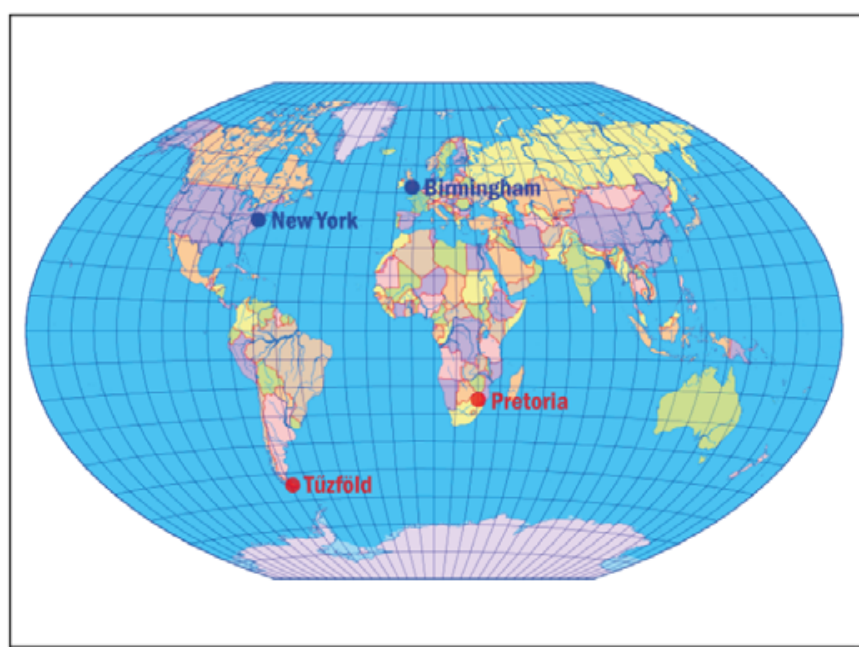

Melyik állítás helyes a légvonalban mért távolság figyelembe vételével?

A) Tűzföld és Pretoria között a távolság közel ugyanakkora, mint New York és Birmingham között.

D) Túzföld és Pretoria között a távolság kb. háromszor nagyobb, mint New York és Birmingham között.
B) Túzföld és Pretoria között a távolság mintegy másfélszer nagyobb, ság nagyjából kétszer nagyobb, mint mint New York és Birmingham között.

E) New York és Birmingham között a távolság mintegy másfélszer nagyobb, mint Pretoria és Tưzföld között.

C) Túzföld és Pretoria között a távol-
ság nagyából kétszer nagyobb, mint
New York és Birmingham között.
$\begin{aligned} & \text { F) New York és Birmingham között } \\ & \text { a távolság nagyjából háromszor na- } \\ & \text { gyobb, mint Pretoria és Túzföld között. }\end{aligned}$

5. ábra. A szakadásokat vizsgáló feladat térképei 


\section{Kísérleti térkép}

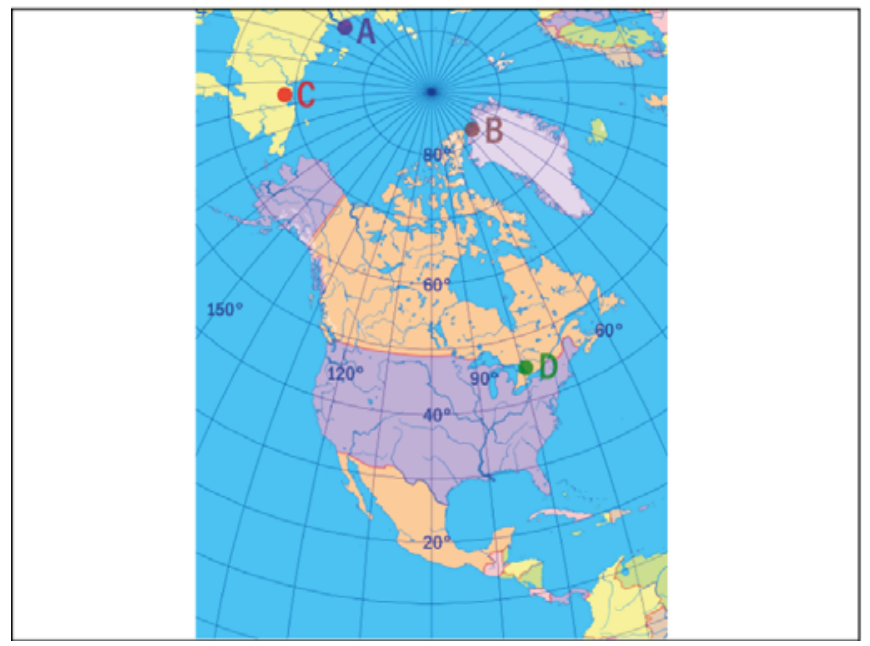

Kontrolltérkép

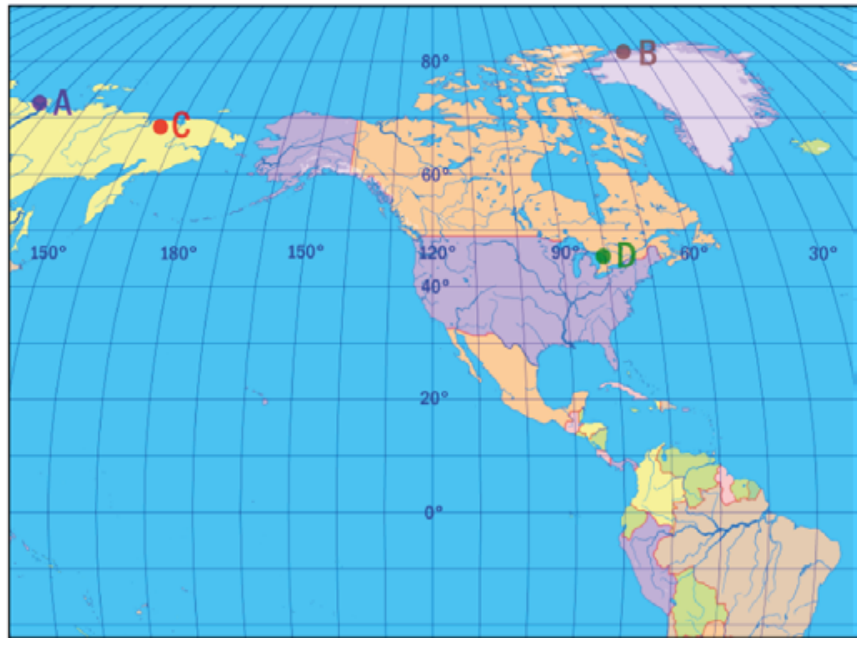

\begin{tabular}{|l|l|l|}
\hline \multicolumn{3}{|c|}{ Rendezze sorba a pontokat a legészakabbitól a legdélebbi felé haladva! } \\
\hline A B C D & A C B D & B A C D \\
\hline B C A D & C D A B & C B A D \\
\hline
\end{tabular}

6. ábra. A fokhálózat értelmezését vizsgáló feladat

A kísérleti csoport 95,6\%-a jelölte meg a helyes, B-A-C-D választ. Hasonlóan kiugró eredmény született a kontrollcsoport esetében, mivel 92,8\%-uk jelölte meg a helyes választ.

Nincs jelentôs eltérés a különbözô változók szerinti bontásban. A legnagyobb különbség az alapfokú végzettségúek esetében figyelhetô meg, a kontrollcsoport javára.

Összességében nem volt számottevô különbség a két vetület között. Kísérleti alanyaink a földrajzi viszonyok értelmezéséhez a fokhálózatra támaszkodtak.

Šavričék (2015) kutatása kimutatta, hogy esztétikai megjelenést tekintve, a képzetes hengervetületek népszerűsége határozottan nagyobb, mint a jobb torzulású egyéb képzetes vetületeké. Ennek ellenére az eredményeink azt mutatják, hogy a fokhálózat bonyolultabb futása nem befolyásolta számottevő mértékben a térkép értelmezhetôségét. Ennek okán nem szükséges feltétlenül képzetes hengervetületben készíteni a világtérképeket, ehelyett megfontolandó a bonyolultabb fokhálózatú, de optimálisabb torzulású vetületeket alkalmazása is.

\section{Pólusvonal}

A magyar iskolai atlaszok piacát hoszszú éveken keresztül uraló Kartográfiai
Vállalat és jogutódjai kerülték a pólusvonalas térképek alkalmazását iskolai kiadványokban. Világtérképeken jellemzően Baranyi IV. vetületét alkalmazták, mely kedvezó torzulású és póluspontos. A tankönyvpiac 2016-os államosítását követôen az új iskolai atlaszokat a Stiefel Kft. készíti, a világtérképeket pólusvonalas Winkel III. vetületűekre cserélték (Fábiánné Merk et. al., 2016). A hagyományokkal történô szakítás apropóján felmértük, a térképolvasók tudják-e egyáltalán, mi a pólusvonal.

Egy korábbi felhasználói teszt (Šavrič et al., 2015) alapján a térképhasználók nem tartják szokatlannak a pólusvonal jelenlétét, nem mutatható ki statisztikai értelemben döntô mértékú preferencia sem a póluspontos sem a pólusvonalas térképek iránt. Kérdôívünkkel utánajártunk, hogy a megszokottsághoz hozzátartozik-e a helyes értelmezés.

Pólusvonalas Robinson-vetületû́ térképünkön egy, a pólusvonal felé álló nyilat követve kellett megmondani, hogy a térképen megjelölt hat pont közül melyiket érintenénk először (7. ábra). Félrevezetésnek az átellenes pólusvonal közelében is helyeztünk el pontokat. A kontrollcsoport a pólus környéki viszonyokat jobban szemléltetô Lambert-síkvetületen dolgozott (7. ábra).
A kísérleti csoport 32,4\%-a jelölte meg a helyes, B választ. Ugyanennyi kitöltô jelölte meg a C lehetôséget, valamint $21,3 \%$ a D-t jelölte válaszul. A kontrollcsoport esetében a résztvevôk 76,6\%-a adott helyes választ.

Minden demográfiai változó esetében szignifikáns különbség lépett fel a kísérleti és kontrollcsoport között. Kivétel nélkül jobb teljesítményt nyújtottak ennél a kérdésnél a kontrolltérképet használók. Ugyanakkor érdekes különbséget tapasztaltunk a nemek között a kísérleti (pólusvonalas) térkép olvasásában. A feladatot a férfiak 43,1\%-a, míg a nôknek csupán 20,3\%-a oldotta meg helyesen. A D választ megjelölôk (akik szerint az északi pólusvonalon kilépve a déli pólusvonalra érkezünk) túlnyomó többsége (75,9\%) nô volt. A kontroll térképen a nemek között már nem volt ilyen eltérés.

Ez egyértelmúen mutatja, hogy a magasabb szélességeket ábrázoló térképeken a póluspontos ábrázolás az ideális megoldás. Ennek fényében érdemes megjegyezni, hogy az újabb iskolai atlaszokban használt világvetület az eredményeink alapján rontja a póluskörnyéki területek értelmezését.

\section{II. irányredukció}

Utolsó kérdésünkben azt kívántuk fölmérni, hogy a térképolvasók mennyire vannak tisztában a geodéziai vonalak 


\section{Kísérleti térkép}

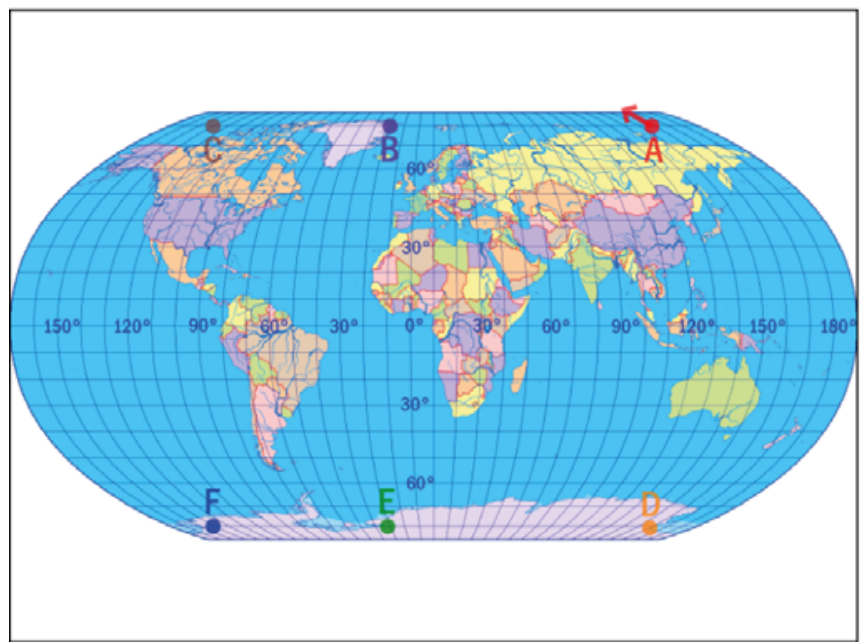

Kontrolltérkép

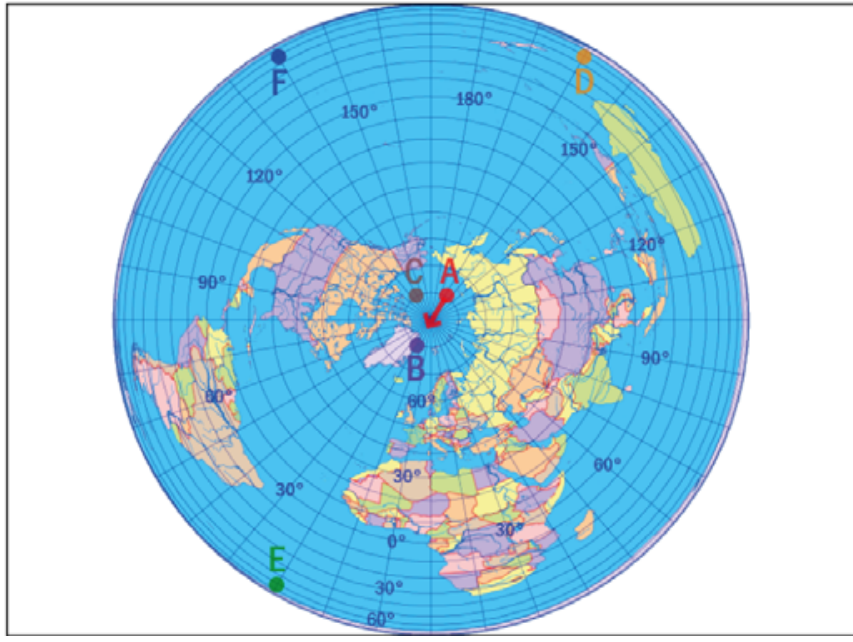

\begin{tabular}{|l|l|l|}
\hline \multicolumn{3}{|c|}{$\begin{array}{c}\text { Ha az A pontból hosszúsági kör mentén, a piros nyíl irányába indulunk, } \\
\text { akkor a térkép melyik pontját érjük el először? }\end{array}$} \\
\hline Vissza az A-ra & B & C \\
\hline D & E & F \\
\hline
\end{tabular}

7. ábra. A pólusvonal értelmezését vizsgáló feladat

térképi görbültségével. Kis méretarányú térképeken hatalmas távolságok is jelen lehetnek, ezért a vetületi síkban mért irányokat a geodéziában szokásosnál nagyságrendekkel erôsebben terheli a második irányredukció, feladatunkban $75^{\circ}$ körüli értéket vett fel.

A világtérképeken szereplố geodéziai vonalak térképi futása rendkívül

\section{Kísérleti térkép}

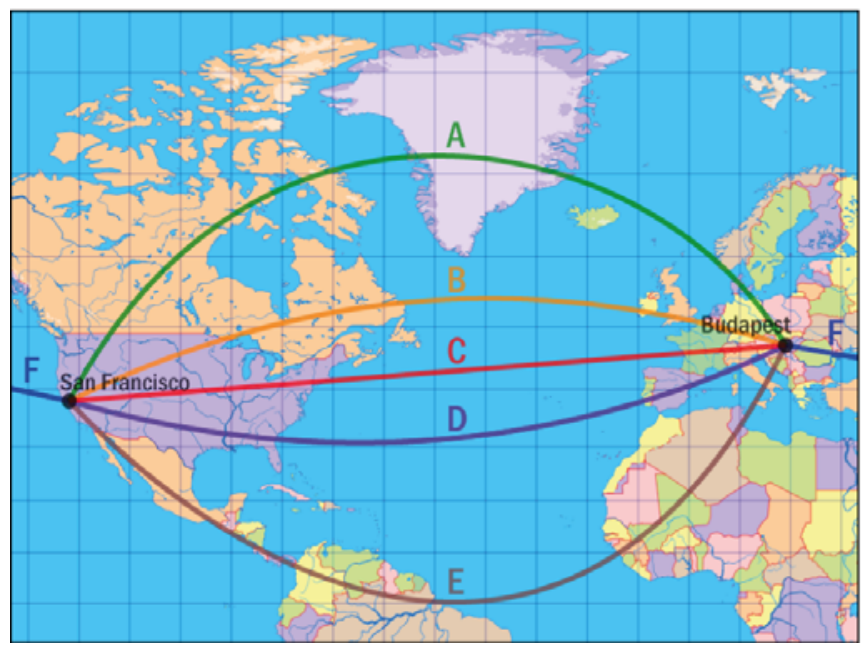

jobban a résztvevők, mert ez gyakrabban szerepel a példákon, és az erôsebb repülóforgalom miatt több a személyes tapasztalat. A tanulmányban nem szerepelt kontrollcsoport.

Vizsgálatunk az elóítéletektól terheltebb északi féltekén folyt, San Francisco és Budapest között kellett a legrövidebb útvonalat a térképrôl leolvasni. Hat, elốre fölrajzolt

\section{Kontrolltérkép}

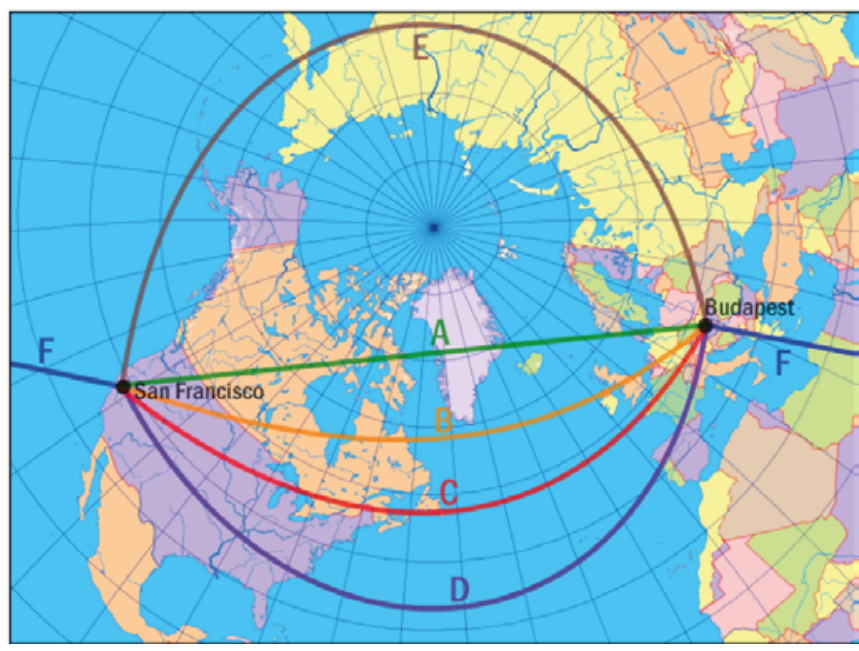

\begin{tabular}{|l|l|l|}
\hline \multicolumn{3}{|c|}{$\begin{array}{c}\text { Melyik útvonalon kell Budapestrôl San Francisco felé repülôgéppel utazni, } \\
\text { ha a legrövidebb utat választjuk? }\end{array}$} \\
\hline A & B & C \\
\hline D & E & F \\
\hline
\end{tabular}

8. ábra. A geodéziai vonalak görbeségét vizsgáló feladat 
útvonal közül lehetett választani, melyek közül egy - félrevezetô módon - a térkép szélén keresztül kötötte össze a városokat. A térkép Miller hengervetületében készült, melyen a meridiánkonvergencia egyáltalán nem, az I. irányredukció pedig elhanyagolható mértékben torzítja az irányokat (8. ábra).

A kontrollcsoport térképét azért nem a II. irányredukciótól mentes gnomonikus vetületben rajzoltuk meg, mert ennek hossztorzulásai bizalmatlanságot kelthettek volna, és az I. irányredukció is zavaró mértékú ekkora távolságnál. Elégségesnek gondoltuk ferde tengelyú valódi síkvetület alkalmazását a geodéziai vonal felezôpontjában fölvett segédpólussal, mert így a vizsgált szakasz egy egyenesre leképeződô segédmeridián lesz. A többi torzulást Airy legkisebb torzulású síkvetületének alkalmazásával hoztuk egyensúlyba (8. ábra). A vetület tulajdonságai miatt nem volt megoldható, hogy a két csoportnál az „E” válaszlehetôség ugyanazon az útvonalon fusson, de itt is ez a válaszlehetôség volt a leghosszabb útvonal.

A kísérleti csoport 42,6\%-a jelölte meg a helyes, A választ. A leggyakoribb helytelen válasz a C lehetôség volt, 25,7\%-kal. A kontrollcsoport 39,6\%-a jelölte meg a helyes választ, a leggyakoribb helytelen válaszra (azaz a C-re) pedig 36,9\%-uk kattintott.

Az adatok vizsgálata alapján ennél a kérdésnél bár szignifikancia nem jelentkezett, de észrevehetôk jellemzó különbségek a kísérleti és kontrollcsoport eredményei közt. A férfiak esetében valamivel jobb eredményt ért el a kísérleti csoport, mint a kontroll, ugyanakkor a nők esetében nem jelent meg számottevô eltérés a két csoport közt. Az életkori kategóriák esetében a 20 év alattiak egyértelmúen jobban teljesítettek a kontrolltérképeken. Ez a tendencia a 25-30 év közöttiek esetében átfordul, és a kísérleti csoport ér el jobb eredményt. A korcsoportokhoz hasonlóan alakult a különbözô iskolai végzettségúek eredménye: míg az alapfokú végzettségúek esetében a kontrollcsoport ért el jobb eredményt, addig a felsôfokú végzettségúek esetében a kísérleti csoport teljesített határozottan jobban. A földrajz- és földtudományokban tapasztaltak esetében szintén a kísérleti térképeken értek el meggyôzốen jobb eredményt a kitöltôk.

A kontrollvetület inkább hátráltatta, mint segítette a helyes értelmezést. A szögtartó világtérképek gyakori alkalmazása miatt a térképhasználók megszokták, hogy a térképi egyenes a valóságban nem az. Ezt a feltevést erôsíti, hogy a fiatalabb kitöltôk esetében jobb eredményt ért el a kontrollcsoport, mint az idôsebb korosztályokban (2630 év közöttiek esetében már a kísérleti csoport teljesített jobban). További érdekesség, hogy a földrajz- és földtudományokban nem jártas kitöltôk kis mértékben jobb eredményt értek el a kontrolltérképen, mint ezen tudományterületekben jártas társaik, akiknél a kísérleti csoport 12 \%-kal jobb teljesítményt nyújtott, mint a kontroll. A férfiak körében lépett fel a legszembetûnőbb különbség, a kísérleti csoport javára. Összességében tehát megállapítható errốl a feladatról, hogy a tapasztaltabb térképolvasók már a „helyes” térképet sem voltak hajlandók torzulásmentesnek elfogadni. Ôk akkor is igyekeztek kiküszöbölni a megszokott torzulást, amikor az nem is lépett fel az adott térképen.

\section{Összefoglalás}

Az eredmények több esetben is alátámasztják Vakabajasi (2013) felvetését, miszerint a kis méretarányú térképek értelmezése tanult folyamat eredménye. Minél gyakrabban lát a térképolvasó adott tulajdonságú térképeket, annál erôsebb prekoncepció alakul ki benne a „helyes” térképekrôl. Ennek alapján a vetületválasztás szerepe is megnô, mivel az nem kizárólag esztétikai kérdés marad, hanem a térképolvasók világról alkotott szemléletét is befolyásolhatja.

Az eredmények azt mutatják, hogy a fiatalabb korosztályt (20 év alattiak) jelentôsebben befolyásolta az alkalmazott vetület, ami arra utal, hogy kevesebb elôítélettel rendelkeznek a vetületeket illetôen. Ez azt jelenti, hogy a fiatalok esetében különösen jelentôs a térképszerkesztôk feladata, hiszen könnyebben befolyásolható ennek a célcsoportnak a világképe. Ugyanakkor meg kell jegyezni, hogy jelen csoport kis létszáma befolyásolhatta a kutatási eredményünket.

Az említett elóítélet leglátványosabban a földrajz- és földtudományokban tapasztalt kitöltőknél jelent meg: ók általában a megszokott vetületeken tudtak jól teljesíteni, a nem szokványos, kisebb torzulású vetületeken a teljesítményük el is maradhatott tapasztalatlan társaiktól.

A kitöltốink körében a legnagyobb kavarodást a pólusvonal jelenléte okozta. Az eredményeinkben kimutatott értelmezési problémák miatt a pólusvonalas vetületeket csak abban az esetben javasolhatjuk, ha a térkép tematikája nem terjed ki magas szélességekre, és a pólusvonalas térkép torzulásai jelentôsen kedvezôbbek lennének a megfelelố póluspontos térképnél.

Összefoglalásul, kutatásunk bemutatta, hogy a vetületek jelentős szerepet játszanak a kis méretarányú térképek olvasásában. Az esztétikai megjelenés mellett figyelembe kell venni a vetületi tulajdonságokat is, mivel a felhasználók térképolvasási képességének fejlôdését is befolyásolhatják.

\section{Köszönetnyilvánítás}

Köszönettel tartozunk az Eötvös Loránd Tudományegyetem Kísérleti Térképészeti Kutatócsoportjának, amelynek keretén belül valósult meg a kutatásunk. Külön hálásak vagyunk Ilyés Virágnak, aki statisztikai ismereteivel segítette az adatfeldolgozást.

Emellett köszönjük Pap Viktóriának, és az ELTE Térképtudományi és Geoinformatikai Tanszék dolgozóinak valamint minden ismerôsünknek a segítségét a teszt terjesztésében!

\section{Irodalom}

Albert, G. - Ilyés, V. - Kis, D. - Szigeti, Cs. Várkonyi D. 2016. Testing The Map Reading Skills of University Students. In T. Bandrova and M. Konecny, (Eds.) 6th International Conference on Cartography and GIS. (pp. 188-199.) Albena: Bulgarian Cartographic Association,

Anderson, K. C. - Leinhardt, G. 2002.: Maps as Representations: Expert Novice Comparison of Projection Understanding. Cognition and Instruction 20/3. pp 283-321. DOI: https://doi.org/10.1207/ $\underline{\mathrm{S} 1532690 \mathrm{XCI} 20031}$ 
Battersby, S. E. - Montello, D. R. 2009. Area Estimation of World Regions and the Projection of the Global-Scale Cognitive Map. Annals of the Association of American Geographers 99/2 pp. 273-291. DOI: https:// doi.org/10.1080/00045600802683734

Böhm, R. - Koch, W. G. - Stams, W. 2017. Erdabbildung in neuer Form - Eine Betrachtung zu Hajime Narukawas Weltkarte. Kartographische Nachrichten $67 / 3$ pp. $117-121$

Fábiánné Merk, Zs. - Szabó, B. - Szabó, M.Nagy, Á. (szerk.) 2016. Földrajzi atlasz középiskolásoknak. Átdolgozott kiadás. Oktatáskutató és Fejlesztô Intézet. Magyar Közlöny Lap- és Könyvkiadó Kft. Budapest. pp. 48-65. ISBN: 978-963-436-004-9

Gilhooly, K. J. - Wood, M. - Kinnear, P R. - Green, C. 1988. Skill in map reading and memory for maps. The Quarterly Journal of Experimental Psychology A: Human Experimental Psychology, 40(October), pp. 87-107. DOI: https://doi. org/10.1080/14640748808402284

Gott III, J. R. - Mugnolo, C. - Colley, W. N. 2007. Map projections minimizing distance errors. Cartographica: The International Journal for Geographic Information and Geovisualization $42 / 3$ pp. $219-234$. DOI: https://doi.org/10.3138/carto.42.3.219

Guzmán, J. F. - Pablos, A. M. - Pablos, C. 2008. Perceptive-Cognitive Skills and Performance in Orienteering. Perceptual and motor Skills, 207, pp. 159-164. DOI: https://doi. org/10.2466/pms.107.1.159-164

Hazay, I. 1954. Földi vetületek. Akadémiai Kiadó, Budapest

Hirtle, S. C. - Jonides, J. 1985. Evidence of hierarchies in cognitive maps. Memory $\&$ cognition $13 / 3$ pp. $208-217$. DOI: $\underline{\text { htps:// }}$ doi.org/10.3758/BF03197683

Hruby, F. - Avelino, M. C. - Ayala, R. M. 2016 Journey to the End of the World Map - How Edges of World Maps Shape the Spatial Mind. GI_Forum (konferenciakiadvány) 1. kötet pp. 314-323. DOI: https://doi.org/10.1553/ giscience 201601 s314

[Ito-Szano] Ito, K. - Sano, Y. 2011. Cultural Differences in The Use of Spatial Information in Wayfinding Behavior. In Proceedings of the 25 th International Cartographic Conference.
Jeney, J. 2015. Problems Caused by Generalisation on Ethnic Maps. In Proceedings of the 27 th International Cartographic Conference.

Ooms, K. - De Maeyer, P. - Fack, V. - Van Assche, E. - Witlox, F. 2012. Interpreting maps through the eyes of expert and novice users. International Journal of Geographical Infor-mation Science, 26(10), pp. 17731788. DOI: https://doi.org/10.1080/1365 8816.2011.642801

Šavrič, B. - Jenny, B. - White, D. - Strebe, D. R. 2015. User preferences for world map projections. Cartography and Geographic Information Science 42/5. pp. 398-409 DOI: https://doi.org/10.1080/15230406.2 015.1014425

[Tolsztova] Толстова, Т. И. 1969. Критерий Эйри в применении к азимутальным проекциям. Геодезия и аэрофотосъёмка 6. pp. 115-118.

Tóthné Parázsló, L. 2011. A kutatásmódszer tan matematikai alapjai. Eszterházy Károly Fớiskola, Eger. ISBN: 987-615-5221-25-5

[Vakabajasi] Wakabayashi Y. 2013. Role of geographic knowledge and spatial abilities in map reading process: implications for geospatial thinking. Geographical Reports of Tokyo Metropolitan University 48. pp 37-46.

\section{Summary}

In the last few years, the Research Group on Experimental Cartography, at the Department of Cartography and Geoinformatics of Eötvös Loránd University, Hungary, created several studies on how map design can affect map reading. Still, these studies only concern large-scale maps (above $1: 100,000$ ), where the distortion of map projections is not considerable. Thus, the goal of the present paper is to study how different map projections affect map reading. To do so, we created an online test where we could see whether the participants are aware of the distortions of smallscale maps, and how these distortions affect the interpretation of the maps. Furthermore, we wanted to define map reading patterns of certain demographic groups (based on age, gender, qualification etc.). These patterns can help cartographers to choose favorable projections for their audience.

Kulcsszavak: vetületválasztás, térképi vetületek torzító hatásai, térképolvasási mintázatok

Keywords: distortion of map projections, map reading patterns

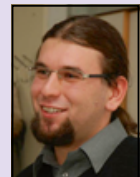

Szigeti Csaba doktorandusz

ELTE, Térképtudományi és Geoinformatikai Tanszék szgtcsaba@map.elte.hu

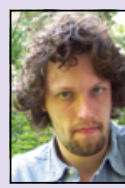

Kerkovits

Krisztián

doktorandusz

ELTE Térképtudományi és Geoinformatikai Tanszék kerkovitskrisztian@gmail.com 